Portland State University

PDXScholar

\title{
From Nativism to White Power: Mid-Twentieth- Century White Supremacist Movements in Oregon
}

Shane Burley

Alexander Ross

Portland State University, aross@pdx.edu

Follow this and additional works at: https://pdxscholar.library.pdx.edu/geog_fac

Part of the Human Geography Commons, and the Politics and Social Change Commons Let us know how access to this document benefits you.

Citation Details

Burley, S., \& Ross, A. R. (2019). From Nativism to White Power: Mid-Twentieth-Century White Supremacist Movements in Oregon. Oregon Historical Quarterly, 120(4), 564-587.

This Article is brought to you for free and open access. It has been accepted for inclusion in Geography Faculty Publications and Presentations by an authorized administrator of PDXScholar. Please contact us if we can make this document more accessible: pdxscholar@pdx.edu. 


\title{
From Nativism to White Power
}

\author{
Mid-Twentieth-Century White Supremacist Movements \\ in Oregon
}

\section{RESEARCH FILES}

by Shane Burley and Alexander Reid Ross

The Ku Klux Klan, a racist, terrorist organization born after the Civil War, was rebooted following World War I. This resurgence was the high-water mark of classic White supremacy ideology in Oregon. By the end of the 1920s, the Klan's influence had died of self-inflicted wounds. The vehicles that would carry White supremacy activism into the next generations of Oregon life were inspired by international strains of anti-Jewish bigotry and competing claims of White Protestant religious destiny - both conjoined with classic notions of nineteenth-century racism. The individuals, organizations, issues, and activities those forces introduced to Oregon culture and politics redefined what White supremacy ideology would look like in Oregon during the second half of the twentieth century.

DURING THE PERIOD between the two world wars, White supremacist organizations in Oregon were influenced by rise of fascism in Germany and Italy. Thoroughly antisemitic and White supremacist, these groups focused outrage against what they misconstrued as outsized Jewish influence in banking and in Franklin D. Roosevelt's administration. Although their membership numbers remained relatively small, these organizations provided a crucial link to the development of radical rightwing groups during the postwar era. ${ }^{1}$

All of these interwar fascist groups in Oregon could appear populist - with their rhetoric outlining a combative relationship between the good, productive "people" and the evil, parasitic "elites" - but racism remained their guiding principle. Leadership repeatedly asserted that the implementation of federal New Deal policies amounted to a consolidation of a Jewish-dominated ruling class responsible for the impoverishment of common people. ${ }^{2}$ The leading scholar of comparative fascist studies, Roger Griffin, argues that fascism is defined by calls for or attempts to reclaim a mythically pure past, and we add that fascism can further be defined as a mass movement 


\section{Hitler Failed...}

He let them live... To have peace and prosperity forever each Nation must kill his own Jews.

When the last hour for the Jew in America strikes there will be NO PASSOVERI

Jews, America is your last Mile! Issued by AMERICAN GENTILE YOUTH MOVEMENT

THE AMERICAN GENTILE YOUTH MOVEMENT distributed stickers such as this one across the country during the late 1930s, according to a 1938 Investigation of UnAmerican Propaganda Activities in the United States hearings report. This and other White supremacist materials are held in the George Rennar Papers at the Oregon Historical Society Research Library in Portland, Oregon.

with intense reliance on specific, collective identities. ${ }^{3}$ In the cases of the groups discussed here - from interwar German-associated organizations to the postwar Christian Identity movement - that sense of identity is linked to White supremacy and is rooted in antisemitism.

We define White supremacy as a set of ideological or institutional precepts attributing superiority of White people over everyone else. While White supremacism is often expressed through individuals or group ideologies, it can also manifest in institutional inequality. ${ }^{4}$ In this discussion of fascist-inspired Whitesupremacist movements of the midtwentieth-century Pacific Northwest, we focus on White supremacism's taking the form of an ideological emphasis on mystical Aryan glory in opposition to a paradoxical loathing of Jews as, simultaneously, rich bankers, Bolsheviks, and federal authorities.

Significant documentation of those interwar organizations in the Pacific Northwest can be found in just two document cases that compose the George Rennar papers in the Oregon Historical Society Research Library. Covering the years 1922 to 1959, the collection includes meeting minutes, correspondence, leaflets, and other primary-source materials that provide glimpses into a variety of interlinked, racist, and nationalist organizations from those years. The documents 


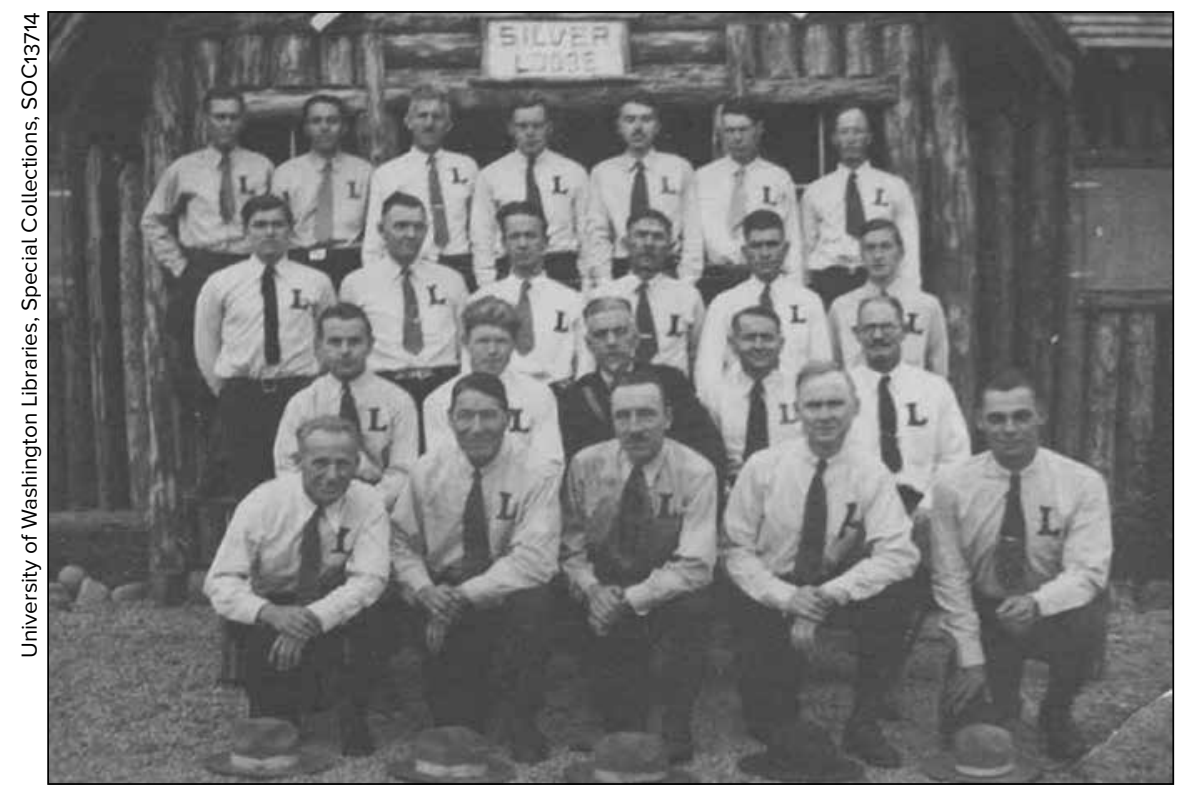

SILVER LEGION OF AMERICA members, also known as Silver Shirts, pose in front of Silver Lodge in Redmond, Washington, in about 1936. William Pelley, pictured in black in the center of the second row from the front, founded the group and embraced White supremacy, antisemitism, racism, and anti-communism.

reveal connections among leaders, some organizing strategies, and both consistencies and changes in espoused ideologies. Some groups documented in the collection, and discussed here, include Friends of New Germany (later the German American Bund, or simply, the Bund), the Silver Legion of America or Silver Shirts, the American Defenders, and Americans Incorporated. At times, the Portland Police's "Red Squad" coordinated with some of these organizations, and membership overlapped. Membership also overlapped with the Ku Klux Klan, which was prominent in Oregon during the 1920 s and has been extensively studied by other historians. ${ }^{5}$ Materials in the Rennar collection indicate important links between the interwar organizations and the more militarized White supremacist, or White nationalist, organizations that took root during the postwar period in the Pacific Northwest. The ideology of British-Israelism - that is, the belief that Anglo-Saxon people and not Jews are the true genealogical descendants of the Bible's "chosen people" - appears as a connecting feature, with spiritual leader William Dudley Pelley a central figure in that connection. ${ }^{6}$

It is possible to say that Pelley's devout Methodist upbringing in a hard-bitten coastal Massachusetts town determined his ambitious rise to American mystic. A talented writer, Pelley imbued into his early stories his millenarian faith in a utopian future of 
direct democracy, which gained him stature enough to leave his East Coast roots for a career in what he called "the necromancy of movie making."7 During the 1920s, Pelley's increasingly arcane mixture of the occult and populism was influenced by prevailing spiritualist ideas of the time as well as his 1918 sojourn through Civil War-ravaged Siberia, where antisemitic attitudes pervaded, and a sense that Jewish producers held back his Hollywood career. His biographer argues that "the great irony of Pelley's work during the 1920 s is that he had to dwell among the libertine residents of southern California to produce defenses of traditional values." At the end of the decade, Pelley experienced a dream-vision that drove him to dedicate himself entirely to mystical pursuits. He understood humans to be refractions of "Love by Vibration" emanating from the "Divine Mind" that was accessible through clairaudient communication with the "harmonious plane" above Earth. ${ }^{9}$ Published in 1929 in the popular American Magazine, Pelley's testimony of spiritual transformation "became one of the most widely read accounts of paranormal activity in American history." He moved to Ashland, North Carolina, to immerse himself in the development of his new cult. As he built a following based on an apocalyptic interpretation of the "Age of Aquarius" and "pyramid dates," around which the universe vibrated most intensely, Pelley came into contact with Nazi ideas. With the rise of Hitler, Pelley converted his mystical sect into a paramilitary political movement, espousing a brand of state corporatism in which White, native-born citizens would own equal shares of national stock, Black people would become "wards of the state," and Jews would be relegated to one city in

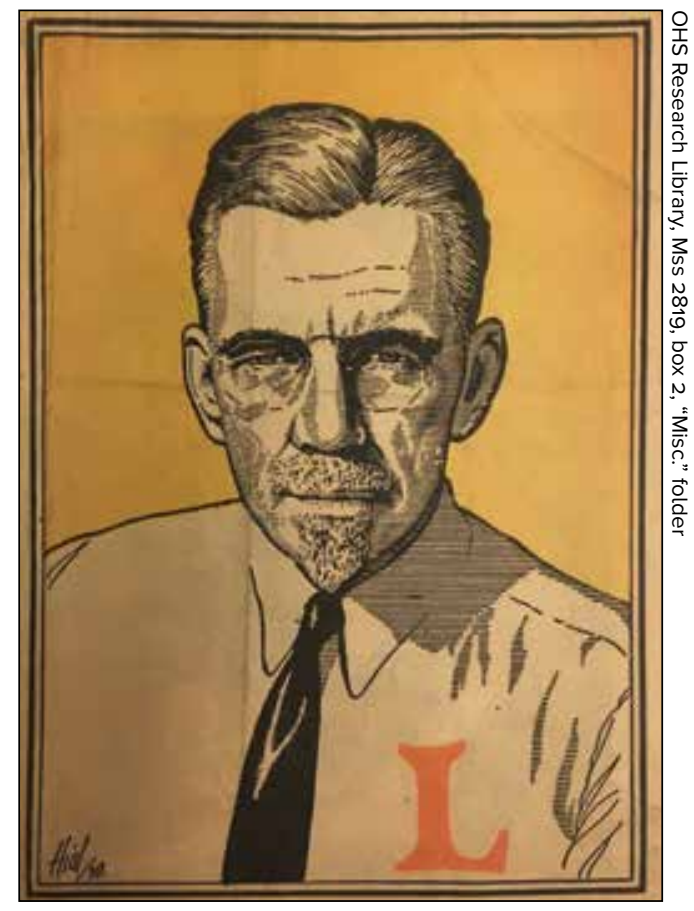

WILLIAM DUDLEY PELLEY is depicted here in a line drawing on a pamphlet titled "What You Should Know About Pelley Publications." Pelley was a central figure in White supremacist movements across the United States, including the Silver Legion of America. In the pamphlet, Pelley explains that readers should ready themselves "with a knowledge of Red-Jewish tactics," so that they will know how to lead "when the aroused Christian element of the nation finally takes the form of vigorous vigilantism." 
each state and would risk death if they strayed beyond those boundaries to migrate. $^{10}$

The emergence of Germany's “New Reich" also stimulated some German immigrants to the United States who blamed the Weimar system for political instability and economic precarity. With the help of the government in 1932, a German immigrant founded a group called Friends of the Hitler Movement to promote the idea of German culture identified with Nazi propaganda. It was soon reorganized and renamed the Friends of New Germany (Bund der Freunde des Neuen Deutschland), and at a national convention in 1936, elected new leadership and became the German-American Bund. Members needed to demonstrate German-language skills and to guarantee that they possessed Aryan racial pedigrees." By the mid 1930s, the Friends of New Germany boasted some 5,000 to 10,000 members nationwide, although its Portland chapter likely never exceeded 100 active members. ${ }^{12}$

In 1934, a Portland newspaper editor named Adam Hochscheid became president of the local chapter of the Friends of New Germany. ${ }^{13}$ Virulently antisemitic, Hochscheid's Nachrichten newspaper became a staunch defender of the Nazi regime, identifying opposition to Nazism with anti-German sentiment. The Hochscheid warned readers of another newspaper that lies were being spread about Germany and publisher Nachrichten publisher, A.E. Kern, provided lists endorsed businesses. ${ }^{14}$ In 1935, according to an informant report, Friends of New Germany members began handing out a flyer that attributed a list of crimes to Jews and encouraged supporters to "Buy Gentile! Employ Gentile! Vote Gentile!"15

The U.S. government declared the Friends of New Germany to be an extension of the German Nazi Party in 1936, and as the group imploded, Hochscheid stepped down from his position as president and focused on the Nachrichten. ${ }^{16}$ Later that year, Friends of New Germany was replaced by the German-American Bund. Within a year of establishment, the German-American Bund claimed about ninety Portland members with roughly the same membership as its predecessor. ${ }^{17}$ What the Bund lacked in numbers it made up for in performative impact. According to an informant report, meetings were held in the backroom of a Portland cafe, "A large colored picture of George Washington occupies a prominent position on the wall facing the membership and a crayon sketch of Horst Wessel, young Nazi, killed in Hitler's abortive 'Beer Hall Putsch' occupies a less prominent position on another wall." ${ }^{18}$

The Bund's Oregon stronghold in Portland was never particularly large relative to some chapters in other cities throughout the country. ${ }^{19}$ While the national membership grew to some 8,500 members, 5,000 to 6,000 "anonymous sympathizers," the only chapters in the Northwest were the Portland, Seattle, and Spokane Ortsgrups, presided over by the Bezirke, based in Oakland. ${ }^{20}$ It is difficult to estimate the total membership in Portland. Average attendance of the meetings was about thirty members, and events could summon up to three hundred members and sympathizers. ${ }^{21}$ To gain clout, the 


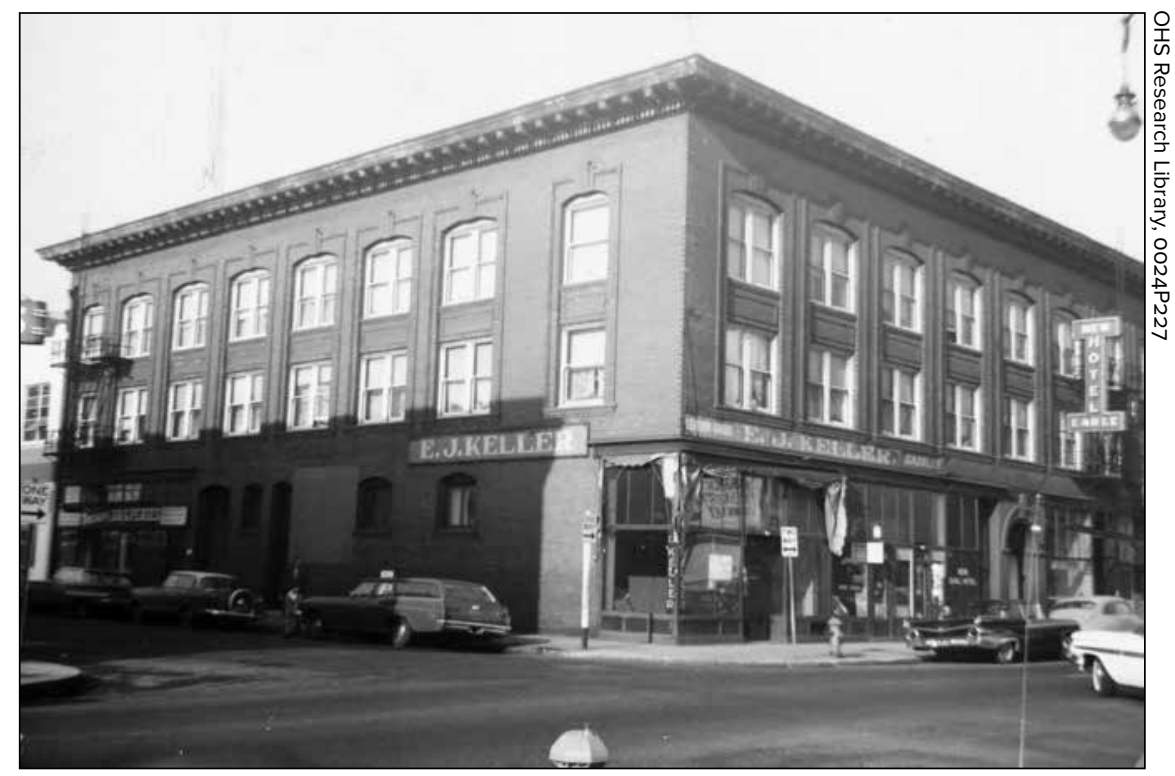

THE NEW EARLE HOTEL, located at what is now Northwest Sixth Avenue and Davis Street in Portland, Oregon, was reported as the location of Friends of New Germany meetings during the 1930 s. Aided by the Nazi government, a group of German-Americans founded the group to promote German culture aligned with Nazi ideals, including Aryan racial pedigrees.

Bund's leadership built bridges with other organizations that organized around antisemitism, especially Pelley's Silver Shirts.

The Silver Shirts first appeared in Portland soon after the national group was established in 1933. Initially caught up in power struggles between former Klan leaders and associates, the openly pro-Nazi Silver Shirts in Oregon grew to some 400 members in Eugene alone by the end of that year. ${ }^{22}$ Meetings included lengthy speeches by White supremacists, Klansmen, and regional organizers such as Roy Zachary, a Seattle restauranteur who helped shape the Washington-based Christian Party as the political wing of the Silver Legion. ${ }^{23}$
Speakers addressed things such as the "communism run by the Jews," and how American citizens will have to stop the threat by use of violence, if necessary. ${ }^{24}$ Talking points at a November 30, 1938, meeting included statements such as:: "Jews claim to have caused all wars of the past 2000 years and brag that they have made therefrom immense profits," and "Jews plan destruction of the American Government in the near future and under the present administration control both government and finance to further these plans." 25 One lecturer discussed "a definite plan of the Jewish Communist to ruin the country," adding that "the International Jewish bankers financed the Russian Revolu- 
tion[,] that two percent of the population were Jewish and they controlled the [sic] 98 percent of the Russian white people." ${ }^{26}$ Articles from Pelley's journal, Liberation, circulated by the Oregon Silver Shirts even suggested genocide. On August 15, 1936, Pelley gave a speech in Portland, which, according to the Oregon Liberal, a weekly broadsheet edited by former Klansman Lem Devers, was attended by some 500 Silver Shirts. ${ }^{27}$

Oregon's Silver Legion remained active through the 1930s, with chapters in The Dalles, Bend, Medford, Toledo, and St. Helens. By 1939, the Silver Shirts boasted 125 neighborhood councils in Portland with between six and twenty members each, as well as several councils across the Columbia River in neighboring Vancouver, Washington. ${ }^{28}$ In 1938, between 250 and 300 people came to hear Zachary speak in Portland. "Every red blooded American citizen should have a good gun and ammunition," Zachary told a captivated crowd. "Put up a target and have your wife practice shooting it if you want to keep a free government." ${ }^{29}$ As one early distributor of Silver Shirts material exclaimed, "look what has happened - the Jews wax fat while gentiles struggle for mere existence." ${ }^{\circ}$ One Pacific Northwest leader suggested that Jews should be fully disenfranchised, and their voting rights provided to Native Americans, continuing Pelley's romanticism about American indigenous people. ${ }^{31}$ The Bund similarly promoted the narrative of the "vast Jewish-Bolshevik conspiracy," in the words of political scientist Leland V. Bell, declaring that their shared purpose with Nazi Germany was to fight the scourge of Communism, which threatened the destruction of America. ${ }^{32}$ Thus, interlocking opposition to Jews as the embodiment of foreignness, elites, and Communism became a central component of a burgeoning movement that implicitly identified Whiteness as the principle criteria for entrance into the national community.

While the Federal Government monitored the Silver Legion and the Bund for dangerous activities, some members of local governments found them useful, particularly as a counterforce to communist influence. The Portland Police Bureau's "Red Squad" did much of the work against left-wing social movement, particularly organized labor, that would have been in line with Silver Legion's politics.. Formed in the 1910 s to monitor radical activities, the secretive "Red Squad" produced a series reports that detailed different groups, that harbored "red" sympathies. By August 1937, the Red Squad's leader, Captain Walter Odale, had joined a Silver Shirts spin-off called the American Defenders. ${ }^{33}$ According to meeting notes, the American Defenders received support from a man named "Kemp" - likely Wilford Kemp, a San Diego millionaire who had been Pelley's running mate on the Christian Party ticket in $1936 . .^{34}$ In turn, the American Defenders contributed $\$ 100$ toward printing Pelley's propaganda and made plans for a "Committee of One Thousand" to serve as a vigilante organization. ${ }^{35}$

Odale wrote that Portland was "reportedly the third largest center of Nazi activity in the United States," in the October 1, 1937, Red Squad "Weekly 
Report of Communist Activities" and asserted: "It can be safely said, that if it were not for the Communist Party, there would be no Fascist or Nazi scare."36 That would prove one of the final Red Squad reports. The Oregonian revealed on October 26, 1937, that Red Squad member and school district board director Louis E. Starr had interrogated a student union leader at Lincoln High School. Public controversy ensued, with the president of the Council for Economic and Social Research stating four days later to city council that the squad's work could "by no stretch of the imagination, be termed engaged in law enforcement." ${ }^{37}$ On October 30, a new group called Americans Incorporated, filed articles of incorporation under Oregon's state laws. ${ }^{38} \mathrm{~A}$ month later, during a business-only meeting of American Defenders, it was reported that should Odale's Red Squad have to stop its activities, "his work and records will be taken over by a new [private] organization, Americans Incorporated." 39

Ten days after that meeting, the first issue of Americans Incorporated's Radical Activities Bulletin came out, picking up where the Red Squad had left off. With lengthy articles on the activities of the Congress of Industrial Organizations (ClO), a labor union's organizing of timber workers, and internal struggles within the Portland School Board, the Radical Activities Bulletin maintained the general drift of the Red Squad's reportage.$^{40}$ It reported that "one Legion post in Milton-Freewater," returned a petition to deport the president of the

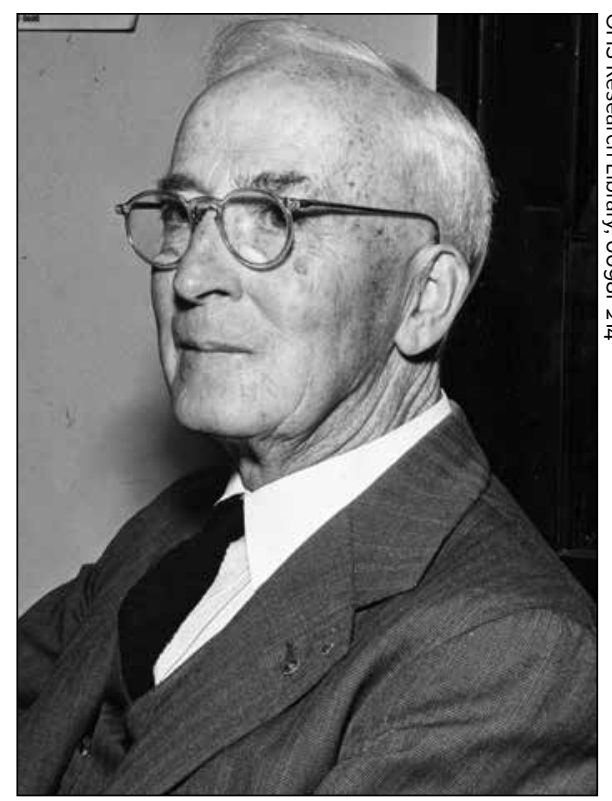

CAPT. WALTER ODALE, pictured here in 1949, led the Portland Police subversive activities detail, or "Red Squad," during the 1930s. Odale's Red Squad integrated with groups such as the Silver Legion and American Defenders in its efforts to quash communist influence, especially among organized labor.

International Woodworkers of America "with 133 signatures obtained in less than three hour's [sic] time." ${ }^{41}$ The organization looked abroad as well, condemning support for the Republicans in the Spanish Civil War as pro-Soviet and anarchistic, while denouncing as a Communist front a Chinese-American picket against a pig iron plant that was sending munitions to the Japanese Empire. ${ }^{42}$ Key members were prominent businessmen and police officers, including Odale, who was on the board of directors, and Louis Starr, who headed up the organization. As the 
Anti-Defamation League's David Robinson noted, the organization attracted "certain fascist individuals who saw an opportunity to ride their hobby under the guise of fighting communism." 43

Americans Incorporated had significant partners. In a February 24, 1939, event at Benson Polytechnic Auditorium, former governor Charles $\mathrm{H}$. Martin performed the task of public honorary chairman at an Americans Incorporated National Defense and Americanism Rally, emceed by Mayor Joseph Carson. ${ }^{44}$ It is difficult to assess the size of Americans Incorporated, partly as a result of the secretive behavior of some of its members, but its influence in high society is indicated by the major politicians who helped to promote the group. Examining Americans Incorporated in light of its obscure origins (out of the cross-over between the Portland police and Silver Shirts, and fostered by the American Defenders) brings to focus the group's role as a public-facing brand of Portland's far-right ecosystem. The existence of a relationship between the Silver Shirts and Portland's police is further illustrated by a February 1940 informant's report found in the Rennar papers, which notes that Silver Shirts boasted of "making excellent progress in the Police Department and that it would be well organized." The report added that the organization's members believed "if any trouble starts in Portland the Police will be with [the Silver Shirts]." 45

The American Defenders, Bund, and Silver Shirts met in houses, cafes, and Portland's Turnverein Hall, run by pro-Nazi activist Otto Uhle, as well as the Harmony Hall, Norse Hall, Wood- man Hall, and Redman Hall, which was associated with a romanticized notion of Native American culture. Historian Roger Griffin has argued that fascists' identification with indigeneity and the representation of an archetypal human community manifest their desire for rebirth of their own mythical, ancestral community, whether Nordic or Italian or "100\% American." 46 In early 1938 , the American Defenders announced they were joining the Americanization Council that was already affiliated with "twenty one patriotic organizations in the city of Portland," including "the German Folksbund and the K.K.K." ${ }^{47}$ Many of the groups listed were relatively small, and there is little evidence that the Americanization Council ever manifested to any public effect.

One of the phenomena that drew together members of the fascist milieu during the 1920 s and 1930 s was the growing popularity in North America of an eccentric body of thought known as British-Israelism. British-Israelists asserted that Anglo-Saxons were the true genetic descendants of Biblical Hebrews. Emerging as early as the sixteenth century, this idea gained popularity during the late nineteenth and early twentieth centuries, fostering a sense of Anglo-American mission in the world. ${ }^{48}$ While many BritishIsraelists thought that the Jewish people were either Khazar "Asiatics" or had originated through a rebellion against the divine commandment not to intermarry with "Edomites," more virulently antisemitic formulations, which formed the basis of the postWorld War II Christian Identity religion, asserted that Jews were the spawn 


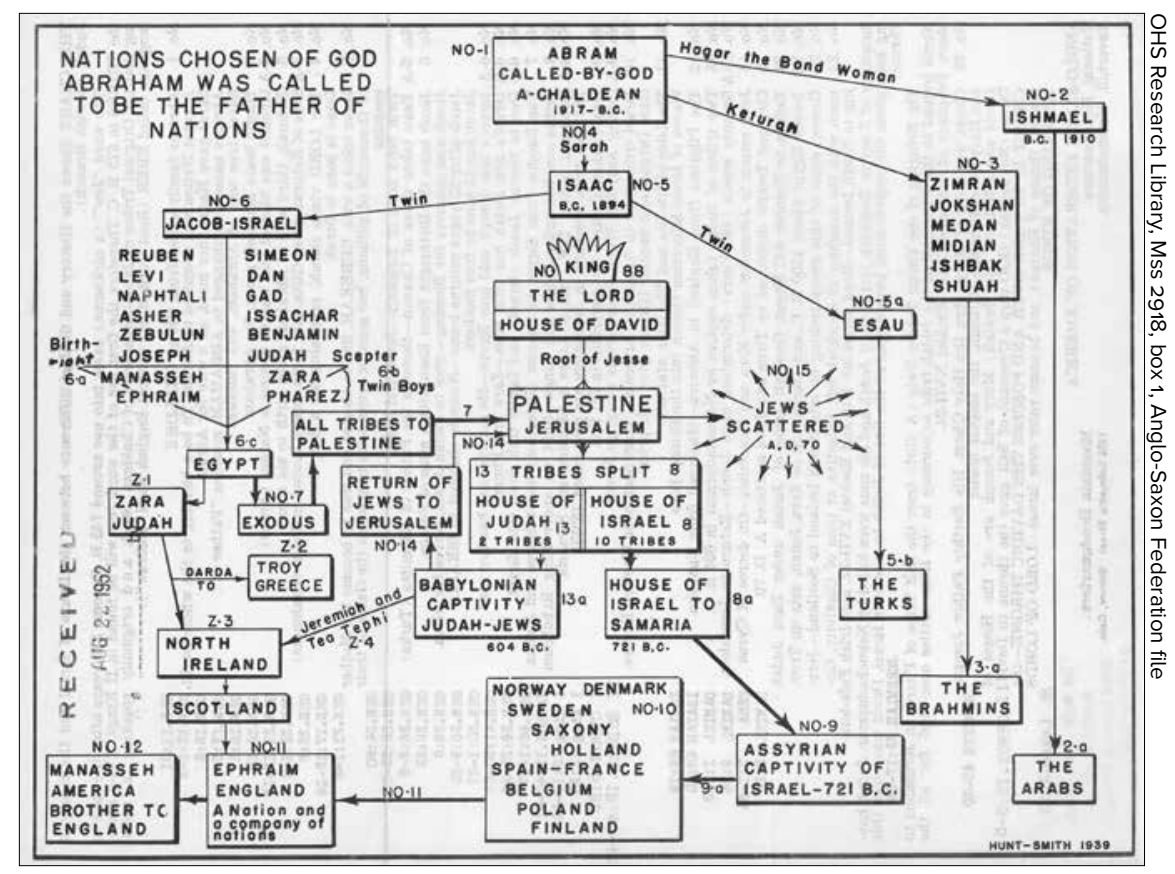

THIS CHART, published by the Anglo-Saxon Federation, provides the group's justification for why Anglo-Saxon people, not Jews, are true descendants of the Bible's chosen people. These views, known as British-Israelism, were shared by many fascist groups during the 1920 s and 1930 s.

of Satan. ${ }^{49}$ In either case, the genetic bearers of the divine covenant, a chosen people, were Anglo-Saxon and not Jewish, according to BritishIsraelism.

One of British-Israelism's prominent acolytes was William Cameron, who, during the 1920s, had edited the Dearborn Independent, the Michigan publication of Henry Ford that published a series on the menace of "The International Jew." In the 1930s, Cameron served on the executive committee of the Anglo-Saxon Federation and lectured in the United States and Canada on the Bible as a "racial book" that told the story of the Anglo-Saxon race. ${ }^{50}$
Connections to British-Israelism run deep in Oregon. Reuben Sawyer, the leading lecturer and organizer for the Oregon Ku Klux Klan, had lectured on British-Israeli principles while serving as a pastor at Portland's Eastside Christian Church during the early 1920 s and played a role in the founding of the British-Israel World Federation in 1920. ${ }^{51}$ A.A. Beauchamp, editor of the British-Israelist publication Watchman of Israel, found the viciousness of Klan antisemitism and racism distasteful, and Sawyer's affiliation with the Klan came to an end in 1924. He remained active in British-Israel circles until the 1930s, when leadership passed into new hands. ${ }^{52}$ 


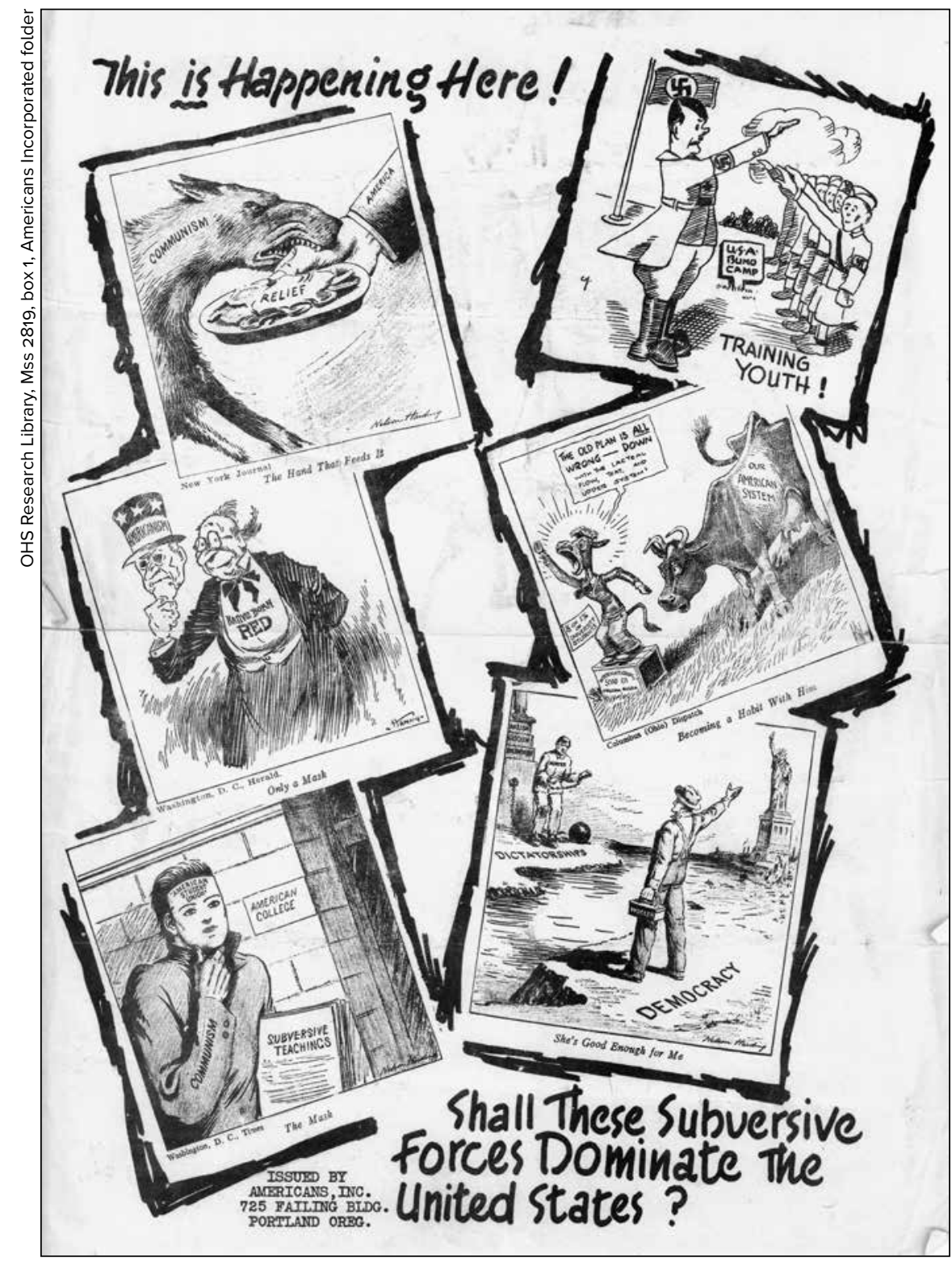

THIS FLYER, titled “Shall These Subversive Forces Dominate the United States?," was distributed by Americans Incorporated. The group was founded in 1937 and continued the work of the Portland Police "Red Squad," railing against forms of foreign extremism, such as communism, dictatorships, and fascism. 
British-Israel gospel spread through the network of Oregon's interwar White supremacist organizations. G. Fred Johnson, president of the Oregon branch of the Anglo-Saxon Federation of America, a British-Israel organization, spoke on themes such as "Masonic History," "Pyramid Symbolism" (a particular obsession of Pelley's), "Racial Origins," and "Israel Truths." ${ }^{3}$ The Anglo-Saxon Federation of America, including Howard B. Rand, who sat on the national commission and the executive council of the British Israel World Federation, obtained support from local Episcopalian and Presbyterian churches and from the Associated Fraternal Societies and Portland Chamber of Commerce. ${ }^{54} \mathrm{An}$ intelligence memo from 1936 noted that, as they made the rounds of churches and luncheons, the British-Israelists' talk "seemed very much like the mouthings of William Dudley Pelley." ${ }^{55}$ The proximity between Johnson, Rand, and the ideology of the Silver Shirts further elucidates the extent of fascist networks that were both within Oregon and tied into larger, transnational ideological systems. That the British-Israelists found such a warm welcome from local religious and political representatives suggests that the Silver Shirts also had a fertile seedbed on which to cultivate their bizarre and occult theories.

THE EXPERIENCE of World War II would forever change the character of fascism in the United States. Amid pressures on fascists from the House Committee on Un-American Activities under Congressman Martin Dies during the late 1930 s and early 1940s, the isolationist movement, which fought
U.S. entry into World War II, had helped promote pro-Axis causes without clear and direct associations with fascism. The movement therefore received, and accepted, the support of fascist groups. ${ }^{56}$ Shortly before the Japanese attack on Pearl Harbor, Oregon Sen. Rufus Holman told fellow lawmakers:

I have always deplored Hitler's ambitions as a conqueror. But he broke the control of these internationalists over the common people of Germany. It would be a good idea if the control of the international bankers over the common people of England was broken, and good if it was broken over the wages and savings of the common people of the United States. ${ }^{57}$

Following the declaration of war on Japan and subsequent dissolution of the national America First Committee, former Silver Shirt Delmore Lessard declared himself the head of Oregon's anti-interventionist America First Committee. ${ }^{58}$ Under the guise of the group that had already officially disbanded, Lessard disseminated pamphlets produced by A.E. Kern \& Co., the same publisher responsible for the Nachrichten. ${ }^{59}$ Following World War II, in 1947, Lessard joined Holman, a former Klansman, to create the anti-Zionist group American Foundation, Inc. ${ }^{60}$

Meanwhile, other Silver Shirts carried on, in spite of the official dissolution of their group in April 1940. Erstwhile Silver Shirts leader Henry Beach consolidated his activities into what he discretely called the "Research Club." Once considered the spokesperson for the Silver Shirts in Oregon, Beach hoped to organize "ten thousand armed people in Portland." ${ }^{11}$ Beach faced pressure from the U.S. army to 
stop his radical activities or leave the West Coast in 1942 after defending Pelley for publishing anti-government materials. He fought to remain in the Pacific Northwest but retreated from far-right politics. ${ }^{62}$

After the war, former Silver Shirts joined with members of other interwar far-right groups to transform the BritishIsraeli interpretation of the Bible into the angrier denial of the humanity of Jews and other minorities. Emerging in California and spreading throughout the Pacific Northwest, the so-called "Christian Identity" movement built on British-Israel origin stories to express White supremacy. Instead of identifying Jews as Asiatics, Christian Identity taught that Jews were the spawn of Satan and that all non-Whites were "mud people" who did not have souls. ${ }^{63}$ Former Silver Shirt John Metcalf, who was inspired both by Pelley's spiritualism and his focus on Jewish conspiracy, came to join the circles around the Christian Identity movement, as did Henry Beach. ${ }^{64}$

Amid the growth of Christian Identity within the increasingly revolutionary far right, an intriguing interplay emerged between above-ground advocacy groups and clandestine paramilitary organizations. By 1951, right-wing activist Irvin Borders had taken the leadership of a new group based in Los Angeles called America Plus, Inc., which attempted to counter disenfranchised ethnic and racial minorities' growing demands for wages and housing. A distinguished retired Marine lieutenant general, Pedro del Valle, who claimed to have known Mussolini "personally and served with his forces in Ethiopia," became involved with America Plus and urged its leaders to endorse his "Minutemen" idea, which would "have a semi-military purpose in checking the violence and sabotage, which the enemy constantly perpetrates in our country." America Plus leaders proved receptive but demanded absolute secrecy. Desperate to stem the tide of the "one-worldists" and "internationalists," del Valle went on to form a new group called the Defenders of the American Constitution, Inc., with other retired military officers. ${ }^{65}$ The secretive militarization of White supremacy that characterized del Valle's paranoid ideas, disseminated in his bulletin TASK FORCE, would find a thriving ecosystem in the Pacific Northwest of the 1950s and 1960 s. $^{66}$

One California-based Christian Identity group founded by Army lieutenant colonel William Potter Gale, called Army of White American Kingdom Evangelists ("Awake"), demanded that its chapter leaders subscribe to del Valle's bulletin and join his Defenders of the American Constitution, Inc. ${ }^{67}$ Gale's close associate, Robert DePugh, took inspiration from del Valle and Gale's ensuing, short-lived paramilitary group, The Rangers, forming a subrosa paramilitary group of his own called The Minutemen to prepare for an incoming Communist assault on the contiguous lower forty-eight states. ${ }^{68}$ DePugh's Minutemen claimed tens of thousands of members, although the FBI estimated their national membership at between 200 and $1,000 .{ }^{69}$ Silver Shirts and Klansmen joined the vigilante Minutemen, which in 1965 plotted to assassinate Martin Luther King, Jr., with 
1,400 pounds of stolen dynamite. Members of the group also allegedly blew up a police station in Redmond, Washington, a town that had been a thriving hub for regional Silver Shirts during the 1930s. They plotted to bomb Redmond's City Hall and rob four banks before the FBI caught up to them in January $1968 .^{70}$

After the FBl's crackdown on the Minutemen, Beach helped pick up the slack of political organizing by piggybacking on Gale's ideas and purportedly establishing the virulently antisemitic Posse Comitatus in Portland, Oregon. ${ }^{11}$ In a later interview with the Oregonian, Beach recalled that the Silver Shirts had been "a very spiritual group" and that Pelley wielded extraordinary metaphysical powers: "Pelley taught me to communicate with the spirit world." ${ }^{2}$ Beach would transfer what he had learned from Pelley to Posse Comitatus, a prototype for the Patriot movement that concentrated resentment against what leaders labeled as an encroaching federal government captured by outside influences often assumed to be Jewish or of a competing, usually Communist, nation. ${ }^{73}$

The post-war far right began reorienting toward Posse Comitatus. One of del Valle's contacts in Oregon, John Birch Society member and Hitler admirer Dean Kennedy, announced that his Lane County chapter of the National Association to Keep and Bear Arms (NAKBA) would join Posse Comitatus en masse,,${ }^{74}$ Claiming to have a

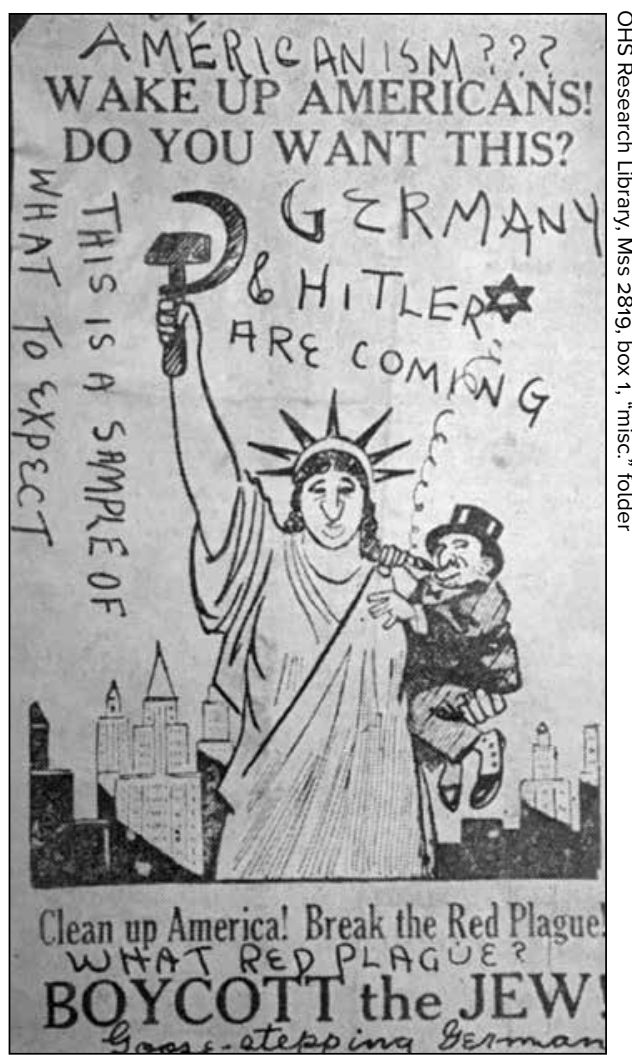

ON JULY 8, 1938, the Astorian-Budget published this image of a an anti-Jewish flyer found in a Portland, Oregon, store window. The image includes hand-written notes on the poster deriding its antisemetic content.

presence in all fifty states, by 1974 , the FBI observed Posse Comitatus chapters in six Oregon counties and labeled the Lane County chapter as the "most active to date." 75 Yet, during the mid 1970 , Beach was openly admonishing recruits to "never let it be known how many members you have. ... Not knowing how many of you there are, makes the TRAITORS more afraid of the influence you have." ${ }^{76}$

Political geographer Carolyn Gallaher has argued that Posse Comitatus 

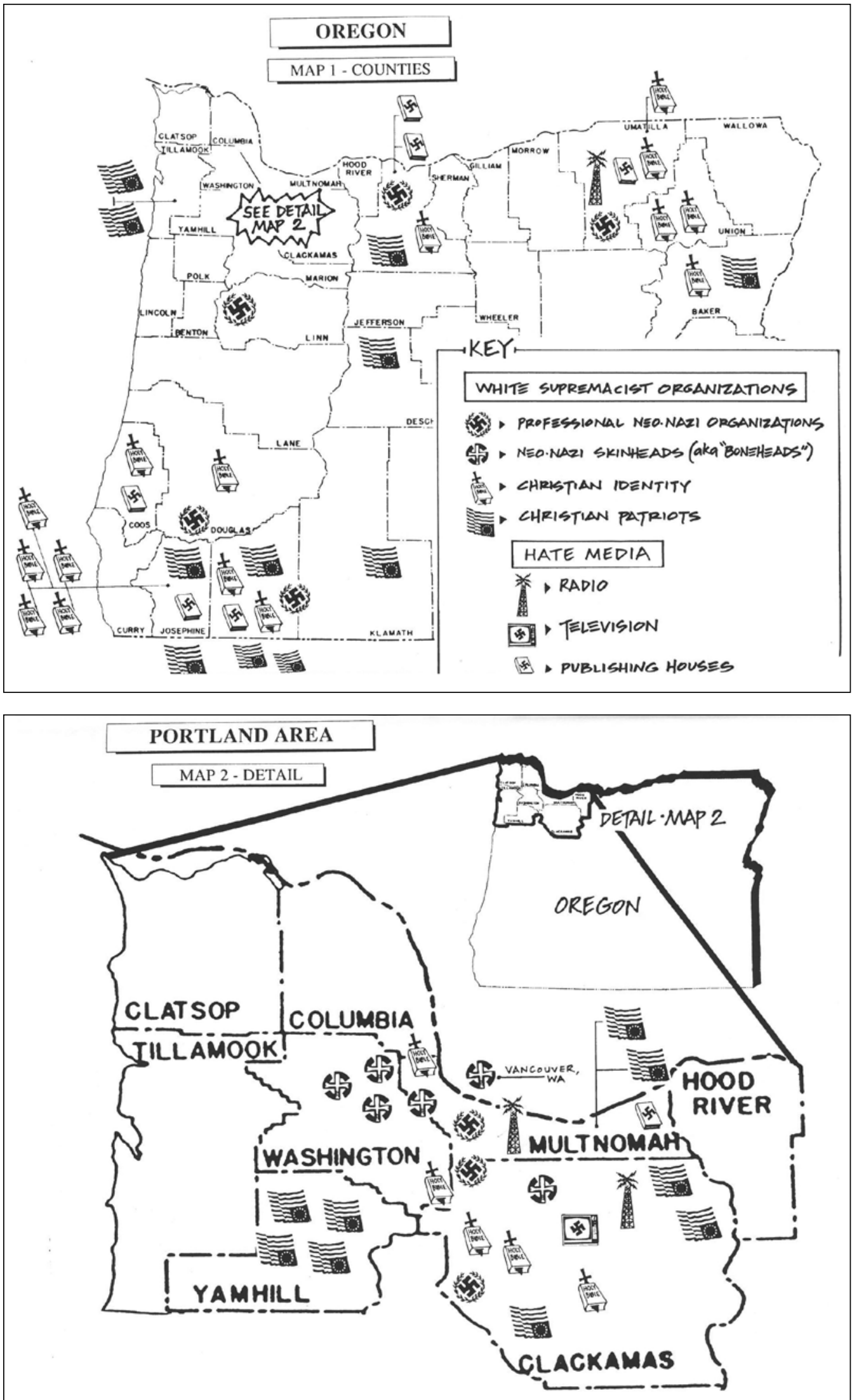
began to gain power by instrumentalizing the rural disenfranchisement stemming from the farm crisis in the Midwest and connecting it to Christian Identity leader Richard G. Butler's calls for a White homeland in the Pacific Northwest. ${ }^{77}$ In 1973, Butler created a Christian Identity compound on Hayden Lake, in Idaho, about eighteen miles from the Washington state line, which became a hub for the most extreme members of Posse Comitatus as well as Klansmen and other extremists bent on race war across Oregon and Washington. ${ }^{78}$ This center for the growing White supremacist movements in the Pacific Northwest facilitated an interconnected network of organized crime responsible for bank robberies and assassinations throughout the 1980s.79 The "White power" movement that had come to roost in the Pacific Northwest was, therefore, not just informed by or imitative of but directly descended from Oregon's interwar White supremacist, fascist movements.

CHRISTIAN IDENTITY took on a much more revolutionary character during the 1970s and 1980s than had earlier British-Israelism, reframing the story of supposed Anglo-Saxon diaspora portrayed as the "lost tribes of Israel" in eschatological terms in which racial enemies (Jews) and subordinates (non-Whites) were enemy combatants in a literal spiritual war that justified acts of violence in the name of Armageddon. ${ }^{80}$ Likewise, Posse Comitatus found a new narrative of rural discontent and form of organizing, one that was revolutionary because it depicted the federal government as captured by alien interests. That shift in ideological intensity and praxis came with a shift in broader conditions, such as the change in social values after the Civil Rights movement, which contributed to the development of the "White power" movement's identity. ${ }^{81}$

The new "White nationalist" or "White power" movement in the postwar period was defined by an explicitly revolutionary character and reliance on vigilante violence pitted as much against the federal government as against African Americans, Latinos, immigrants, and members of the LGBTQ community. ${ }^{82}$ White nationalists have tried to distinguish themselves from White supremacists by defining their movement as the ideological pursuit of White political sovereignty and social separation from non-Whites; however, this distinction does not absolve White nationalists from being identified as White supremacists, because their ideology is simply a particular strategic implementation of White supremacy. ${ }^{83}$

In our study of the materials available regarding interwar fascist groups and their immediate allies, as well as the ensuing White power movement

LEFT: These two maps, published in a 1990 Coalition for Human Dignity report titled Organized White Supremacist Groups in Oregon, document White supremacist organizations that existed throughout the state. The report highlights over two dozen groups operating in Oregon at the time of publication. As the keys indicate, the maps point out the types of organizations, their location, and the type of media used to spread their messages. 


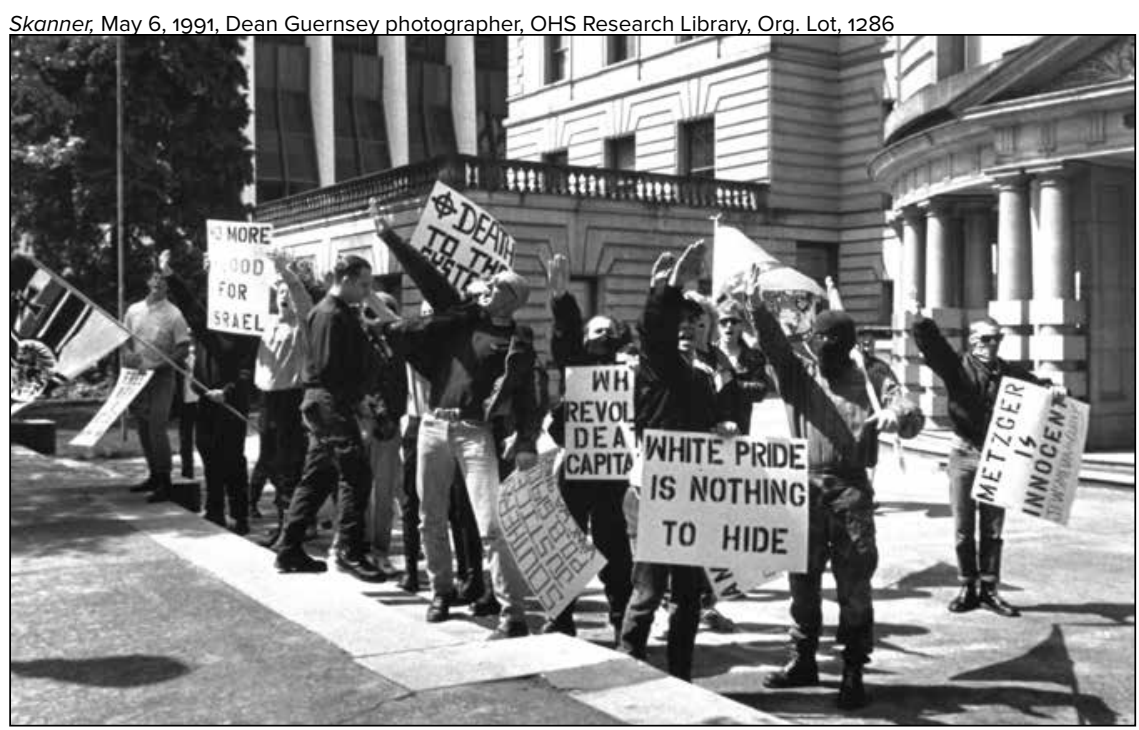

ON MAY 5, 1991, White supremacists gathered outside Portland City Hall to protest the civil trial ruling against Tom Metzger, who was found financially liable for the recruitment of Skinheads in Portland, leading to Mulugeta Seraw's murder in 1988. According to the Oregonian, the rally was organized by the White supremacist group American Front, and was met with about one hundred counter protesters.

that developed through their postwar networks, we have found several important points. First, the interwar period appears to have been a time of coalition, through which AngloSaxon supremacy promoted by the Ku Klux Klan in the 1920s gave way to a more marginal assemblage of identitybased, far-right groups, including occult British-Israelists and German-American supporters of the Nazi Party. "Aryan" heritage in opposition to Jewish hegemony appears to have been the glue that ensured this coalescence. Second, we uncovered elements within Oregon's political establishment, including members of the police, that supported groups intertwined within the fascist networks around the American Defend- ers. Hence, the marginality of the identity-bound fascist groups was folded into a broader far-right ecosystem that included Portland's then-mayor Carson, former governor Martin, then-Senator Holman, and police officers such as Odale. Meanwhile, fascist groups and their allies were surveilled by the AntiDefamation League and the $\mathrm{FBI}$, adding to the complexity.

Our research suggests that, as a result of federal opposition during World War II, those who had been engaged with the Silver Shirts during the interwar period increasingly began to mobilize in opposition to the government and in favor of White political sovereignty. Rhetoric of "Aryan" heritage and Jewish hegemony was replaced, 
in more public-facing discourse, with conspiracy theories about a "One World Government" and "internationalist" bankers, providing a more accessible milieu for recruitment from a broad pool of political affiliations. With the rise of Donald Trump as President and of "Independent Trumpist" organi- zations, such as Patriot Prayer and their Alt Right bedfellows that bring fascism to bear again in cities such as Portland, we can see how the interwar fascist movement, while ultimately a failure, helped sow the seeds for today's rural discontent as manifested in the modern Patriot movement. ${ }^{84}$

\section{NOTES}

The authors want to thank Larry Lipin for substantial editorial assistance.

1. The literature on fascist organization in Oregon is much less extensive than that on the Ku Klux Klan, reflecting the smaller size of the movement. See Eckard Toy, "Silver Shirts in the Northwest: Politics, Prophecies, and Personalities in the 1930s," Pacific Northwest Quarterly 80 (October 1989): 139-46.

2. Cas Mudde defines populism as a movement that sees two groups in antagonism with each other, a corrupt elite and the pure people. Cas Mudde, The Far Right in America (New York: Routledge, 2018), 2-3. See also, Martin Durham, White Rage: The Extreme Right and American Politics (New York: Routledge, 2007), 8.

3. Roger Griffin, Fascism: An Introduction to Comparative Fascist Studies (Cambridge: Polity Press, 2018), 40-45; Roger Griffin, The Nature of Fascism (New York: Routledge, 1991), 34-40.

4. George M. Fredrickson, White Supremacy: A Comparative Study in American and South African History (New York: Oxford University Press, 1981), xi.

5. See, for example, Eckard Toy, "The Ku Klux Klan in Oregon," in G. Thomas Edwards and Carlos A. Schwantes, eds., Experiences in a Promised Land: Essays in Pacific Northwest History (Seattle: University of Washington Press, 1986); Toy, "Robe and Gown: The Ku Klux Klan in Eugene, Oregon, during the 1920s," in Shawn
Lay, The Invisible Empire in the West: Toward a New Historical Appraisal of the Ku Klux Klan of the 1920s (Champaign: University of Illinois Press, 2004); David A. Horowitz, "Order, Solidarity, and Vigilance: The Ku Klux Klan in La Grande, Oregon," in Lay, The Invisible Empire in the West; David A. Horowitz, "The Klansman as Outsider: Ethnocultural Solidarity and Antielitism in the Oregon Ku Klux Klan of the 1920s," Pacific Northwest Quarterly 80 (January 1989): 12-20; Paul M. Holsinger, "The Oregon School Bill Controversy, 1922-1925,"

Pacific Historical Review 37 (August 1968): 327-41; Robert D. Johnston, The Radical Middle Class: Populist Democracy and the Question of Capitalism in Progressive Era Portland, Oregon (Princeton: Princeton University Press, 2003), 223-47; and Linda Gordon, The Second Coming of the KKK: The Ku Klux Klan of the 1920s and the American Political Tradition(New York: Liveright Publishing, 2017).

6. Materials relating to the ideology of BritishIsraelism can be found in Mss 2918, George Rennar papers [hereafter Rennar papers], box 1 , Anglo-Saxon Federation folder, Oregon Historical Society Research Library, Portland, Oregon [hereafter OHS Research Library].

7. Scott Beekman, William Dudley Pelley: A Life in Right-Wing Extremism and the Occult (Syracuse: Syracuse University Press, 2005), 1-2, 41.

8. Ibid., 41. 
9. Ibid., 55, 70-71.

10. Ibid., 57, 77-78, 86.

11. James E. Geels, "The German-American Bund: Fifth Column of Deutschtum?) (M.A. thesis North Texas University, 1975), 53-59; Bureau of Immigration, Portland Office, "The GermanAmerican Bund," report prepared in 1941, Rennar papers, box 1, Friends of New Germany folder 2, OHS Research Library.

12. Francis MacDonnell, Insidious Foes: The Axis Fifth Column and the American Home Front (Oxford: Oxford University Press, 1995), 43. The Portland chapter estimate is based on documents available in the Rennar papers, box 1, Friends of New Germany folders 1 and 2, OHS Research Library.

13. U.S. Department of Justice, Immigration and Naturalization Service, Portland, Oregon, "File no. 235-4093, Record of Sworn Statement made by Otto F. Decker," Rennar papers, box 1, Friends of New Germany folder 1; Howard L. Fenn, Naturalization Examiner, Portland, Oregon, June 23, 1941, p. 2-3, Rennar papers, box 2, Silvershirt Legion of America [hereafter Silver Shirts] folder; "Report for Week Ending 3/31/34," Rennar Papers, box 2, Silver Shirts folder, all held at the OHS Research Library.

14. A. Hochscheid, Letter to editor, February 27, [no year], box 1, August Hochscheid folder, OHS Research Library; "Where do you buy? Support those Firms that Advertise in the 'Nachrichten',' Rennar papers, box 2, A.E. Kern \& Co. folder, OHS Research Library.

15. U.S. Department of Justice, Immigration and Naturalization Service, Portland, Oregon, "File no. 235-4093, Record of Sworn Statement made by Otto F. Decker," Rennar papers, box 1, Friends of New Germany folder 1.

16. Ibid. See also, Frank C. Hanighen, "Foreign Political Movements in the United States," Foreign Affairs 16:1 (October 1937):6-7.

17. Silver Shirts meeting report, February 10 , 1939, Rennar Papers, box 2, Silver Shirts folder, OHS Research Library.

18. "Report: Activities of Portland branch German American Bund [mid-1938]," Rennar Papers, box 1, Friends of New Germany folder 1, OHS Research Library. Anna Bernstein, Swastika Nation: Fritz Kuhn and the Rise and Fall of the German-American Bund (New York: St. Martin's Press, 2013), 189.
19. Gretchen Jane Guber, View Master: The Biography of William B. Gruber (Minneapolis, MN: Mill City Press, 2014), 140.

20. Leland V. Bell, "The Failure of Nazism in America: The German American Bund, 19361941" Political Science Quarterly 85:4 (1970): 589; U.S. Federal Bureau of Investigation, "German American Bund (Amerika Deutscher Volksbund)," New York City, November 17, 1941, p. 6, https://vault.fbi.gov/german-american-bund/ german-american-federation-bund-part-11-of-10 (accessed November 18, 2019).

21. "Memorandum," November 6, 1937, Rennar Papers, box 1, Friends of New Germany folder 1, OHS Research Library.

22. Groups included former Klan editor Lem Dever and Roy Metcalf's National Brotherhood, on one hand, and Fred Gifford's National Crusaders, on the other. See "Satus of antis," early November 1933, Rennar papers, box 2, Silver Shirts folder, OHS Research Library. A Portland observer wrote in a letter that in 1933 "one of the local Italian societies joined en masse," see C.W. Houghtailing to Henry J. Berkowitz, December 29, 1933, Rennar papers, box 2, Silver Shirts folder, OHS Research Library. On Pelley, see Suzanne G. Ledboer, "The Man who would be Hitler: William Dudley Pelley and the Silver Legion," California History 65:2 (June 1986): 127-36; Scott Beekman, William Dudley Pelley: A Life in right-Wing Extremism and the Occult (Syracuse: Syracuse University Press, 1995), 63-71, 80-90. Also useful is Eckard V. Toy, "Silver Shirts in the Northwest."

23. Toy, "Silver Shirts in the Northwest," 142.

24. Silver Shirts Meeting Report, June 16, 1938, Rennar Papers, box 2, Silver Shirts file, OHS Research Library.

25. Silver Shirts Meeting Report, November 30, 1938, Rennar Papers, box 2, Silver Shirts file, OHS Research Library; "Report of Meeting of the Silver Shirt Region, Turn Verein Hall, Portland, Oregon," June 16, 1938, Rennar papers, box 2, Silver Shirts file, OHS Research Library.

26. Silver Shirts lecture and meeting report, February 10, 1939?, Rennar Papers, box 2, Silver Shirts folder, OHS Research Library.

27. "Portland Jews in Danger of Losing Many Friends," Oregon Liberal, 1:18, September 11, 1936, pg. 1, Rennar Papers, box 2, Lem Devers folder, OHS Research Library. See also Rennar papers, 
Silver Shirts folder held at OHS Research Library.

28. Silver Shirts meeting report, February 10, 1939, Rennar papers, box 2, Silver Shirts folder, OHS Research Library. These numbers were likely inflated, since they came from the Silver Shirts themselves.

29. "Report of Meeting of the Silver Shirt Region, Turn Verein Hall Portland, Oregon," June 16, 1938, Rennar Papers, box 2, Silver Shirts folder, OHS Research Library.

30. Silvers, November 1933, Rennar papers, box 2, Silver Shirts folder, OHS Research Library.

31. Silver Shirts meeting report, November, 20, 1938, Rennar papers, box 2, Silver Shirts folder, OHS Research Library.

32. Bell, "The Failure of Nazism in America," 587.

33. Untitled American Defenders meeting notes, September 17, 1937, Rennar papers, American Defenders folder, OHS Research Library.

34. Untitled American Defenders meeting notes, October 23, 1937, Rennar Papers, American Defenders folder, OHS Research Library; Untitled American Defenders meeting notes, December 4, 1937, Rennar Papers, American Defenders folder, OHS Research Library.

35. Untitled American Defenders meeting notes, October 9, 1937, Rennar Papers, American Defenders folder; Untitled American Defenders meeting notes, December 24, 1937, Rennar Papers, American Defenders folder, OHS Research Library.

36. Walter Odale, "Weekly Report of Communist Activities, Bureau of Police, Portland, Oregon," October 1, 1937, Rennar Papers, box 1, Portland Police folder, OHS Research Library.

37. "'Red Squad' Head Quizzes Student," Oregonian, October 26, 1937; "City 'Red Squad' Flayed by Chief of Research Body," Oregonian, October 31, 1937.

38. J.H. Hazlett, Corporation Department, State of Oregon, to Arthur A. Goldsmith, attorney, December 22, 1937, Rennar papers, Americans Incorporated folder, OHS Research Library; David Robinson, "Preliminary Organization Report," October 17, 1941, Americans Incorporated, Rennar papers, box 1, American Defenders folder, OHS Research Library.

39. American Defenders Meeting Report, December 4, 1937, Rennar papers, box 1 ,
American Defenders folder, OHS Research Library.

40. A number of Radical Activities Bulletins covering these subjects are located in the Rennar papers, box 1, Americans Incorporated folder, OHS Research Library.

41. Americans Incorporated, Radical Activities Bulletin, Portland, Oregon, no. 14, March 11, 1938, Rennar papers, box 1, Americans Incorporated folder, OHS Research Library. The report also noted that Australian-born Harry Bridges, who founded the International Longshore and Warehouse Union (ILWU) in 1937, should also be named on the petition. For more on Harry Bridges and the ILWU in Portland, see Sandy Polishuk, "They can't come in the front door because you guys won't let them," Oregon Historical Quarterly 120:4 (Winter 2019): 546-61.

42. Americans Incorporated, Radical Activities Bulletin, no. 14, March 11, 1938, Rennar Papers, box 1, Americans Incorporated folder, OHS Research Library; Americans Incorporated, Radical Activities Bulletin, no. 14, March 11, 1938, Rennar papers, Americans Incorporated folder, OHS Research Library.

43. David Robinson, "Preliminary Organization Report," October 17, 1941, Rennar Papers, box 1, Americans Incorporated folder, OHS Research Library.

44. "Fascist Party," Portland Voter, July 30, 1938, Rennar papers, box 1, Americans Incorporated folder, OHS Research Library; Louis E. Starr to Myer Rubin, February 14, 1939, Rennar papers, box 1, Americans Incorporated folder, OHS Research Library.

45. Report, February 29, 1940, Rennar Papers, box 2, Silvershirt Legion of America folder, OHS Research Library.

46. Meeting places are named throughout the Silvershirt Legion of American folder in box 2 of the Rennar papers at OHS Research Library. Roger Griffin, "The Primacy of Culture: The Current Growth (Or Manufacture) of Consensus within Fascist Studies," Journal of Contemporary History 37:1 (2002): 21-43.

47. American Defenders Meeting Report, January 8, 1938, Rennar papers, box 1, American Defenders folder, OHS Research Library. Fred Gifford had revived the Klan in 1937, claiming that the primary focus was to fight both "communism and fascism in this country" and to keep the U.S. 
"safe for the democratic principles that made it great." "Klan Revival Due in Oregon, Gifford Says," Oregon Journal, October 19, 1937.

48. Michael Barkun, Religion and the Racist Right: The Origins of the Christian Identity Movement (Chapel Hill: University of North Carolina Press, 1997), 18-27.

49. Ibid., 121-70.

50. Barkun, Religion and the Racist Right, 22-26, 31-40.

51. Ibid., 22-23.

52. Barkun, Religion and the Racist Right, 22-26; Lawrence M. Lipin, "Reexamining the Oregon Klan in the Age of Trump: True Believers and Fellow Travelers," Common Knowledge, Pacific University, https://commons.pacificu.edu/ ashist/1/ (accessed November 18, 2019).

53. Business card for G. Fred Johnson, Lecturer, Rennar papers, box 1, Anglo-Saxon Federation folder, OHS Research Library. Rand's public talks throughout the month of September included luncheons in Portland at the Rose City M.E. Church, Church Forum in the Imperial Hotel, the Multnomah Civic Club at the Congress Hotel and in Salem and Clatskanie at the American Lutheran Church. See 1936 handbill published by the Anglo-Saxon Federation of America, Oregon Headquarters, Portland, Oregon, Rennar Papers, box 1, Anglo-Saxon Federation folder, OHS Research Library.

54. "Dr. Howard B. Rand Here Saturday," Clatskanie, Ore., Chief, September 11, 1936. According to an informant memo, Rand also met with Portland's Mayor on September 11, 1936, Rennar papers, box 1, Anglo-Saxon Federation folder, OHS Research Library. See also, "Trunkful of Theories," Statesman Journal, September 16, 1936.

55. "Memo" April 21, 1936, Rennar papers, box 1, Anglo-Saxon Federation folder, OHS Research Library.

56. Manfred Jonas, "Pro-Axis Sentiment and American Isolationism," The Historian, 29:2 (1967): 221-25.

57. "Wheeler, Holaman Scored as Injecting Anti-Semitism in Lend-Lease Debate," Jewish Telegraphic Agency, March 6, 1941, https://www. jta.org/1941/03/06/archive/wheeler-holmanscored-as-injecting-anti-semitism-in-lend-lease- debate (accessed November 15, 2019).

58. Letter from Delmore Lessard, Acting Chairman, Oregon Chapter, America First Committee, April 30, 1941, Rennar Papers, box 2, Misc. folder, OHS Research Library.

59. David Robinson (Reporter), Preliminary Organization Report, Oct 17 1941, George E. Rennar Papers.

6o. For more information on American Foundation, Inc., see the "American Foundation, Inc." file in the George E. Rennar Papers, which includes newspaper clippings and the group's articles of incorporation.

61. Alphabetical List of Individuals, HIA-R, Barnhart Collection, N-5D-3-125-7, p. 11 and "Silver Shirt Legion of America, January 9, 1943, HIA-R, Barnhart Collection, N-5D-3-125-7, p. 9-11, https://digitalcollections.hoover.org/images/ Collections/78006/HIA-R-BARNHART-EDWARDN-5D-3-125-7.pdf (accessed November 18, 2019); Daniel Levitas, The Terrorist Next Door: The Militia Movement and the Radical Right (New York: Palgrave Thomas Dunne Books, 2002), 118.

62. Levitas, The Terrorist Next Door, 118-20.

63. See Barkun, Religion and the Racist Right, 199-254; and Nicholas Goodrick-Clarke, Black Sun: Aryan Cults, Esoteric Nazism, and the Politics of Identity (New York: New York University Press, 2002), 236-41.

64. See Toy, "Silver Shirts in the Northwest," 144.

65. See letter exchange between del Valle to Irvin Borders of America Plus, sent August 14, 1951, and a response from American Plus via Aldrich Blake sent October 3, 1951. Regarding his claim about Mussolini, see de Valle's letter sent August 9, 1962, and addressed to National States Rights Party organizer J. Paul Thornton. For quotes on "one-worldism" and "internationalists" see TASK FORCE, April 1955. This material is available in Pedro Del Valle papers, 1949-1978, University of Oregon Libraries, Coll 126. These sources are included in an excellent summary of del Valle's work, which can be found in Kevin Coogan, "The Defenders of the American Constitution and the League of Empire Loyalists: The First Postwar Anglo-American Revolts against the 'One World Order', a paper delivered at Amsterdam International Institute for Social History, 2004 
66. For instance, among Del Valle's myriad correspondents was Dean Kennedy, a John Bircher and Defenders of the American Constitution member who led a strange anti-gun-control group called the National Association to Keep and Bear Arms, based in Medford, Oregon. That group's acronym, NAKBA, is the same word Palestinians use to describe the mass displacement following the Arab-Israeli War of 1948, suggesting perhaps the same ultranationalist anti-Zionism that characterized del Valle's own antisemitic writings. To view their correspondence, see Pedro Del Valle papers, 1949-1978, University of Oregon Libraries, Coll 126. For more on Kennedy, see Levitas, Terrorist Next Door, 115-16, 120, 137.

67. Federal Bureau of Investigation, LA 157-571, “William Potter Gale," January 22, 1964, p. 3, https://archive.org/stream/GaleWilliamP. HQ1/Gale\%2C\%2oWilliam\%20P.-HQ-1_djvu.txt (accessed November 18, 2019).

68. Steward A. Wright, Patriots, Politics, and the Oklahoma City Bombing (Cambridge: Cambridge University Press, 2007), 58-61.

69. Ibid, 60.

70. Silver Shirts built a "Silver Lodge" in Redmond and congregated there during the 1930s. See McNamara, N. and "Temple For 'American Hitler' Once Stood In Redmond: Knute Berger," Redmond Patch, May 29, 2018, https://patch.com/washington/redmond/templeamerican-hitler-once-stood-redmond-knuteberger (accessed November 16, 2019). See also Silver Shirt Legion of America, Washington State Division photograph collection, circa 1930s, PH1521, University of Washington Libraries, http://archiveswest.orbiscascade.org/ ark:/80444/xv84258; James Aho, The Politics of Righteousness: Idaho Christian Patriotism (Seattle: University of Washington Press, 1995), 57; and "7 ARE CONVICTED IN PLOT ON COAST: Guilty of Conspiring to Rob Banks for Minutemen," New York Times, June 23, 1968.

71. While some sources follow Beach's claim to have founded Posse Comitatus in 1969, Leonard Zeskind insists that Gale founded the group in 1971 and Beach plagiarized him. Zeskind, Blood and Politics: The History of the White Nationalist Movement from the Margins to the Mainstream (New York City: Farrar Straus Giroux, 2009), 72.
72. Quoted in Toy, "Silver Shirts in the Northwest," 144. Levitas similarly claims that Gale disliked Beach's promotion of the group. See Levitas, The Terrorist Next Door, 116.

73. Levitas, Terrorist Next Door, 108-111; FOIA documents acquired by Levitas from FBI, Sheriffs Posse Comitatus, Portland, OR: FBI, PD 157-1432, archived here: https://archive.org/ stream/SheriffsPosseComitatusDetroit15710687/ Sheriffs\%20Posse\%20Comitatus \% 20-\%20 Detroit\%20157-10687_djvu.txt (accessed November 16, 2019); Aaron Winter, "Posse Comitatus," Religion and Violence: An Encyclopedia of Faith and Conflict, ed. J. I. Ross, (Armonk: M.E. Sharpe, 2011), 575-80

74. Levitas, Terrorist Next Door,120.

75. Ibid.

76. Ibid., 119.

77. Carolyn Gallaher, "On the Fault Line: Race, Class and the US Patriot Movement," Cultural Studies, 16:5 (2002): 673-703.

78. Kathy Marks, Faces of Right Wing Extremism (Boston: Branden Books, 2011), 85, 139.

79. Timothy G. Baysinger, "Right-wing Group Characteristics and Ideology," Homeland Security Affairs 2, Article 3 (July 2006).

80. On the Christian Identity movement, see George Michael, Theology of Hate: A History of the World Church of the Creator (Gainesville: University of Press of Florida, 2009), 49-50.

81. Aaron Winter, "Posse Comitatus," 57580.

82. Kathleen Belew, Bring the War Home: The White Power Movement and Paramilitary America (Cambridge: Harvard University Press, 2018), 106-117, 127, 140.

83. George Hawley, Right-Wing Critics of American Conservatism. Lawrence: University of Kansas Press, 2016), 246. It should be noted that in this case, it is pursuing political separation motivated by their belief in in their inherent supremacy.

84. Spencer Sunshine, "The Growing Alliance Between Neo-Nazis, Right Wing Paramilitaries and Trumpist Republicans," Colorlines, June 9, 2017, https://www.colorlines. com/articles/growing-alliance-between-neonazis-right-wing-paramilitaries-and-trumpistrepublicans (accessed November 18, 2019). 